\title{
Extraversion-Introversion Personality Traits Of Local Firm CPAs Who Previously Worked For A National CPA Firm: An Empirical Study
}

David Satava, (Email: satavad@uhv.edu), University of Houston-Victoria Dan Hallock, (Email: dehallock@una.edu), University of North Alabama

\begin{abstract}
Prior research on the personality types of CPAs has focused on which personality types were most attracted to national or local public accounting firms. Previous studies indicate that national-firm CPAs are twice as likely to be extraverts whereas local-firm CPAs are twice as likely to be introverts. No prior studies have evaluated the extraversion-introversion personality types of those who first started with a national firm before working for a local firm. This study postulates that for extraversion-introversion, CPAs who worked for a national firm before working for a local firm are statistically similar to those who have only worked for a local firm and statistically different from those who have only worked for a national firm. With respect to extraversion-introversion for those who first started work for a national firm before working for a local CPA firm, this study supports the hypothesis that they would be different from those who had only worked for a national firm and does not support their similarity with those who had only worked for a local CPA firm.
\end{abstract}

\section{INTRODUCTION}

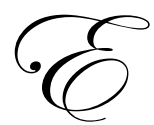

ach year between 22 and 28 percent (AICPA, 2002) accountants employed by national public accounting firms (Big 4) are fired, advised to leave, and or leave voluntarily and seek employment elsewhere. The same AICPA survey indicates that the turnover rate for local public accounting firms (defined as a CPA firm that is not recognized as a Big 4 national public accounting firm) is between seven and ten percent. Thus, even though the national firms' starting pay is significantly more than local firms', the turnover rate at the national firms is at least two to three times higher than a local firms'. The turnover figures for national firms is disheartening since according to Scarbrough (1993) national public accounting firms traditionally focus their recruiting on hiring accounting graduates who rank in the top of their graduating class. Because of a desire to remain practicing CPAs, many who leave the national firms end up working for local public accounting firms.

Wheeler (2001) states that the amount of published research on the personality types of CPAs is surprisingly small. The last study on the personality types of CPAs was conducted by Schloemer and Schloemer (1997) and was consistent with prior studies (Jacoby 1980; Otte 1984; and Satava 1996) which had focused on identifying which personality types were most attracted to the public accounting profession and have consistently found, based on Myers-Briggs typology, that two of the 16 personality types (ISTJs and ESTJs) comprised over 40 percent of those employed in public accounting. One study (Satava, 1996) found that national-firm CPAs were twice as likely to be extraverts (E) whereas local-firm CPAs were twice as likely to be introverts (I).

Prior research on the personality types of CPAs divided the public accounting firms into two groups (national and local firms). Within local firms, researchers treated CPAs as similar (Otte, 1990; Scarbrough and Scarbrough, 1997) with respect to their public accounting career antecedents. This is not the case, since with respect to their public 
accounting career local firm CPAs have either worked solely for local public accounting firms or have previously worked for a national firm prior to working for a local firm. This latter group, those CPAs who started their public accounting careers with a national firm prior to working for a local public accounting firm has not been studied before, and therefore represents the main focus of this study.

No prior studies have been conducted to determine whether the E - I personality type of CPAs who previously worked for a national firm before working for a local firm are more similar to the CPAs in the national firm they left or to the local firms they now work for. It is hypothesized with respect to extraversion-introversion that CPAs who previously worked for a national accounting firm prior to working for a local accounting firm will be more similar to CPAs working for local CPA firms than to CPAs who work for national accounting firms. Since previous studies have consistently found that CPAs' personality trait, with respect to Sensing-Intuition, Thinking-Feeling, and Judging-Perceiving, are similar, regardless of the type of CPA firm they work for, these personality traits are not the focus of this study.

This study divides the CPA respondents into three groups: a) those who have only worked for a national firm, b) those who first started working for a national firm and now work for a local public accounting firm (hereafter known as national-to-local professionals), and c) those who have only worked for a local public accounting firm.) If the results of this study find, that with respect to extraversion-introversion, that national-to-local CPAs are more similar to CPAs in local firms than to CPAs in national firms, this information could be useful to public accountants who desire to increase their job longevity by finding the type of CPA firm best suited to their personality. This information could also be useful to professors and counselors who assist college students with respect to their choice of careers.

\section{PSYCHOLOGICAL TYPE THEORY}

According to Hammer and MacDaid (1992) the theory of psychological type postulates that the distribution of individuals into jobs or occupations is not a random process. They contend that when individuals seek employment, they want to find career opportunities that help them express their personality preferences, achieve career satisfaction, and obtain financial rewards for doing what they like to do. According to Myers and McCaulley (1985) people choose occupations for a variety of reasons, including the challenge of the job, money, location, family management, influence of teachers, desire to assist others, amount of leisure time, and their co-workers. Myers and McCaulley go on to state that with respect to motivation, people select their occupation based on whether it is intrinsically interesting and satisfying. Personality type theory posits that the distribution of individuals into various occupations represents an effort by individuals to find work they like to do, are good at, and find interesting and challenging. Thus, according to Hammer and MacDaid, to the extent that individuals succeed in their effort to find employment compatible to their personality types, there should be an observable relationship between psychological type and occupational choice with respect to the type of firm an individual ends up working for.

\section{PERSONALITY RESEARCH AND MYERS-BRIGGS}

Cattell (1965) defined personality as that which tells what a person will do when placed in a given situation. According to Consulting Psychologists Press, (1993) the exclusive distributor of Myers-Briggs material, the MBTI is used in business and education for career counseling, team building, and conflict resolution and management development. The Myers-Briggs Type Indicator was used to identify whether the CPAs in this study were extraverts or introverts. According to Myers and Myers (1980) extroversion is concerned more with the outer world of people, places, and things while introversion is concerned with the inner world ideas and concepts. The extravert focuses on the outer world and draws energy from large groups while the introvert prefers to focus on the inner world of ideas, concepts, and prefers to interact with smaller groups of people.

\section{HYPOTHESES}

Prior research on CPAs has primarily focused on the descriptive statistic of how many of the sixteen different personality types of Myers-Briggs work in a public accounting firm. Hammer and MacDaid (1993) note that while 
there is ample evidence that personality type is related to occupational choice, they further state that the relationship between personality type and occupational choice is far from perfect. One of the reasons for this might be that prior research on personality type and occupational choice has not considered the impact of the type of firm a person works at in evaluating the relationship between personality type and occupation. Sheridan (1992) found that firms that value the interpersonal relationships of their CPAs more than the completion of work tasks kept their employees, on average, at least 18 months longer.

With respect to extraversion-introversion, there are two distinct differences between the corporate culture of a national and local firm. One of the main differences between a national public accounting firm and local accounting firm is the amount of emphasis that national firms place on their employees' seeking and obtaining new clients. Extraverts would be expected to find the social aspect of client development, with the frequent social interactions interesting while introverts would find it uncomfortable. This may be one of the reasons that Satava (1996) found twice as many extraverts than introverts working for a national firm. Secondly, with respect to extraversion-introversion, national firm employees would, as they move up the hierarchy, be interacting and supervising more employees within their firm. Satava (1997) found a correlation between personality type, with respect to extraversion and introversion, and the number of people directly supervised. There was a statistically significant difference between extraverts and introverts in regard to the number of people they supervised, regardless of the firm type.

Thus, it would be natural for extraverts to seek employment with the national firms while introverts would seek out employment with the local firms. Because none of the previous studies about CPAs evaluated the personality types of those individuals who first were employed by a national firm before working for a local firm, it is postulated that with respect to extraversion-introversion, the national-to-local professionals will be more closely aligned or similar to those who have only worked for a local CPA firm (introversion). These same individuals (national-to-local professionals), with respect to extraversion-introversion, would be statistically dissimilar to those who have only worked for national firms.

Ho $^{1}$ : The extraversion-introversion percentage rate will be statistically similar to those in past studies regardless of whether a CPA has always worked for a national accounting firm, local public accounting firm, or is identified as a national-to-local professional.

\section{METHODOLOGY}

Of the 1505 questionnaires sent out, 432 questionnaires were properly completed and returned for this study and represent a response rate of 28.7 percent. Respondents were asked to complete the Myers-Briggs Type Indicator (MBTI) in order to determine their preference for extraversion-introversion. In addition, respondents answered demographic questions about gender, job specialty (auditing, consulting, and tax), type of firm they work for (national or local), and whether they had previously worked for a national firm if they currently worked for a local firm. Table 1 provides a breakdown of the respondents by gender and job specialty as they relates to the type of firm they currently work for. Respondents were then classified into three groups with respect to the types of CPA firms they have worked for (national only, national to local, and local firm only).

\section{ANALYSIS OF RESULTS}

All of the respondents in this study are CPAs who passed the uniform national CPA examination and meet the work and educational requirements of their state. The CPAs in this study, those who first started with a national firm before finding a job with a local CPA firm, were fired, asked to resign, and or voluntarily resigned from a national accounting firm. Thus many of these professionals were identified by a national firm as weak employees whereas a few who left on their own accord may have been seeking a different working environment, more money, and or professional advancement opportunities not available with a national firm. Subsequent to leaving the national accounting firms, all of the respondents in this study, who previously worked for a national firm, subsequently obtained employment with a local CPA firm, thus indicating a desire to stay in public accounting, rather than seek 
employment in private or governmental accounting. It could be said that the national-to-local firm CPAs in this study were seeking a second chance to stay in public accounting.

This study hypothesizes that the national-to-local professionals would have an extraversion-introversion ratio similar to those CPAs who had worked only for a local firm. It hypothesizes that the national-to-local professionals would have an extraversion-introversion ratio statistically different from those who had worked only for a national accounting firm. Table 2 provides a percentage breakdown of the extraversion-introversion personality types as they relate to the three categories of CPA employment.

Table 1a: Study Respondents - Gender By Firm Type

\begin{tabular}{|l|c|c|c|}
\hline Type of firm & Total & Male & Female \\
\hline National firms only & 198 & 147 & 51 \\
\hline National to local firm & 83 & 58 & 25 \\
\hline Local firm only & 151 & 84 & 67 \\
\hline & 432 & 289 & 143 \\
\hline
\end{tabular}

Table 1b: Study Respondents - Rank By Firm Type

\begin{tabular}{|l|c|c|c|}
\hline & National to Local Firm & National Firm Only & Local Firm Only \\
\hline Staff & 0 & 10 & 9 \\
\hline Senior & 6 & 38 & 42 \\
\hline Manager & 16 & 97 & 22 \\
\hline Partner & 61 & 53 & 78 \\
\hline Totals & 83 & 198 & 151 \\
\hline
\end{tabular}

Table 1c: Study Respondents - Job Specialty By Firm Type

\begin{tabular}{|l|c|c|c|}
\hline & National to Local Firm & National Firm Only & Local Firm Only \\
\hline Auditing & 32 & 127 & 39 \\
\hline Consulting & 8 & 28 & 14 \\
\hline Tax & 43 & 43 & 98 \\
\hline Total & 83 & 198 & 151 \\
\hline
\end{tabular}

Table 2: Analysis Of Extraversion-Introversion (E-I) By Firm Type

\begin{tabular}{|l|c|c|c|c|c|}
\hline Type of firm & $\mathbf{n}=$ & E & I & & \\
\hline A. National firms only & 198 & $63 \%$ & $37 \%$ & $*$ & $* *$ \\
\hline B. National-to-local & 83 & $46 \%$ & $54 \%$ & $*$ & \\
\hline C. Local firm only & 151 & $37 \%$ & $63 \%$ & & $* *$ \\
\hline
\end{tabular}

Chi-Square Calculations: * There is a significant statistical difference between A and B $(\mathrm{p}<.01)$. **There is a significant statistical difference between $\mathrm{A}$ and $\mathrm{C}(\mathrm{p}<.001)$. There is no significant statistical difference between $\mathrm{B}$ and $\mathrm{C}$

In Table 2, Chi-Square calculations indicate that there is significant difference between extraversionintroversion for those professionals who had worked only for a national firm and those identified as national-to-local professionals. Furthermore, in Table 2, there was no significant statistical difference, with respect to extraversionintroversion for national-to-local professionals as compared with those who had worked only for a local firm. There was found to be a significantly statistical difference, with respect to extraversion-introversion, when comparing national firm CPAs to local firm CPAs.

After reviewing the results of this study, based on a univariate statistical analysis (chi-square), the study was extended to include and control for differences that might be in the population based on gender or job specialty. Table 3 includes an analysis of variance (Anova) for extraverts and introverts (E-I) by firm type and gender. Per the Anova in Table 3a, controlling for gender, there is a statistically significant difference $(\mathrm{P}<$. 0001) for extraversion- 
introversion and the type of CPA firm a respondent was classified too. Per Table 3c, all three possible combinations of comparisons between the firm types, with respect to extraversion-introversion, controlling for gender, were found to be statistically significant $(\mathrm{p}=.05$ ). Per Table $3 \mathrm{a}$, with respect to extraversion-introversion, there was no statistical difference for gender, while the interaction between type of firm and gender found a statistically significant difference $(\mathrm{p}=.0321)$.

Further analysis of this interaction, per Table $3 b$, indicates that more female introverts than female extraverts changed from a national to a local firm. Table $3 b$ indicates that significantly more national firm females are extraverts than introverts, whereas, this table indicates that significantly more local firm females are introverts than extraverts. Thus, the national firms have significantly more extraverts than introvert, regardless of gender. The females in this study who changed from a national firm to a local firm were similar to the females who had only worked for a local CPA firm, with respect to extraversion-introversion.

With respect to the male CPAs in this study, percentage-wise, there were more extraverts than introverts who changed from a national CPA firm to a local firm CPA firm. As noted above, there were significantly more extraverted males (percentage wise) who worked solely for a national firm, than there were introverts. Per Table $3 \mathrm{~b}$, those males who were identified as working only for a local CPA firm were predominately introverts. Thus, the males who identified as national-to-local firm CPAs, were more similar with respect to extraversion-introversion, to the national firm CPAs than to the local firms. This is in contrast to the females (identified as national-to-local firm CPAs), . who were found to be more similar, with respect to extraversion-introversion, to the local CPA females than were the males in this study who changed from a national CPA firm to a local firm CPA firm.

Table 3a: ANOVA Of Extraverstion-Introverstion (E-I) By Firm Type And Gender

\begin{tabular}{|l|c|c|c|c|c|}
\hline & DF & Sum of Squares & Mean Squares & F-Value & P-Value \\
\hline Type of Firm & 2 & 6.417 & 3.209 & 13.621 & $<.0001$ \\
\hline Gender & 1 & .420 & .420 & 1.752 & .1827 \\
\hline Interaction & 2 & 1.633 & .817 & 3.466 & .0321 \\
\hline Residual & 426 & .236 & .236 & & \\
\hline
\end{tabular}

Table 3b: Means Table By E-I And Gender

\begin{tabular}{|l|c|c|c|c|c|c|}
\hline Type of Firm and Gender & Count & E & I & Mean* & Standard Deviation & Standard Error \\
\hline National-2-Local FEMALE & 25 & 8 & 17 & 1.680 & .476 & .095 \\
\hline National-2-Local MALE & 58 & 34 & 24 & 1.414 & .497 & .065 \\
\hline National Only FEMALE & 51 & 36 & 15 & 1.294 & .460 & .064 \\
\hline National Only MALE & 147 & 90 & 57 & 1.395 & .490 & .040 \\
\hline Local Only FEMALE & 67 & 27 & 40 & 1.657 & .478 & .058 \\
\hline Local Only MALE & 84 & 33 & 51 & 1.607 & .491 & .054 \\
\hline Total & 432 & & & & & \\
\hline
\end{tabular}

*Extraversion $=1$, *Introversion $=2$

Table 3c: Fisher's PLSD For Extraversion-Introversion (E-1) By Firm Type

\begin{tabular}{|l|c|c|c|c|}
\hline Type of Firm & Mean Difference & Critical Difference & P-Value & \\
\hline Nat-2-Local vs. National Only & .125 & .125 & .0490 & S \\
\hline SSNat-2-Local vs. Local Only & -.135 & .130 & .0422 & S \\
\hline National Only vs. Local Only & -.260 & .103 & $<.0001$ & S \\
\hline & & & & \\
\hline
\end{tabular}

$\mathrm{S}=$ Statistically Significant Difference 
Table 4 includes Anova for extraversion-introversion (E-I) by firm type and job specialty. Per the Anova in Table $4 \mathrm{a}$, controlling for job specialty, there is a statistically significant difference $(\mathrm{P}=.0015)$ for extraversionintroversion and the type of CPA firm a respondent was classified too. Per Table 4a, at the $\mathrm{p}=.05$ level, there was no statistical difference for job specialty as it relates to extraversion-introversion. While $p=.0529$ is quite close to $p$ $=.05$, a further analysis of Table $4 \mathrm{c}$, as it relates to the comparisons of job specialty and extraversion-introversion, did not find any statistically significant differences. A review of Table $4 \mathrm{~b}$ does indicate that when comparing CPAs in the national firms to the CPAs in the local firms, there does appear to be more introverts in auditing (percentage wise) than in consulting. It is further noted that the sample size for the consulting group $(n=8)$ is rather small compared with the sample of national-to-local firm CPAs. With respect to the local firms, when comparing the auditors to the consultants, there are significantly more introverts (percentage wise) auditors than introverted consultants. It is also noted that the sample size for the consulting group $(n=15)$ is rather small when compared with the entire local firm sample size. In addition, there was no statistically significant interaction between type of firm and job specialty $(\mathrm{p}=$ .0928).

Table 4a: ANOVA Of Extraverstion-Introverstion (E-I) By Firm Type And Job Specialty

\begin{tabular}{|l|c|c|c|c|c|}
\hline & DF & Sum of Squares & Mean Squares & F-Value & P-Value \\
\hline Type of Firm & 2 & 3.102 & 1.551 & 6.601 & .0015 \\
\hline Job Specialty & 2 & 1.391 & .695 & 2.960 & .0529 \\
\hline Interaction & 4 & 1.885 & .471 & 2.006 & .0928 \\
\hline Residual & 423 & 99.368 & .235 & & \\
\hline
\end{tabular}

Table 4b: Means Table By E-I And Job Specialty

\begin{tabular}{|l|c|c|c|c|c|c|}
\hline Type of Firm and Job Specialty & Count & E & I & Mean* & $\begin{array}{c}\text { Standard } \\
\text { Deviation }\end{array}$ & $\begin{array}{c}\text { Standard } \\
\text { Error }\end{array}$ \\
\hline National-2-Local Auditing & 32 & 14 & 18 & 1.562 & .504 & .089 \\
\hline National-2-Local Consulting & 8 & 6 & 2 & 1.250 & .463 & .164 \\
\hline National-2-Local Tax & 43 & 28 & 15 & 1.468 & .508 & .077 \\
\hline National Only Auditing & 127 & 78 & 49 & 1.354 & .480 & .043 \\
\hline National Only Consulting & 16 & 10 & 6 & 1.375 & .500 & .125 \\
\hline National Only Tax & 55 & 33 & 22 & 1.400 & .494 & .067 \\
\hline Local Only Auditing & 39 & 7 & 32 & 1.821 &. .389 & .062 \\
\hline Local Only Consulting & 14 & 7 & 7 & 1.500 & .519 & .139 \\
\hline Local Only Tax & 98 & 42 & 56 & 1.571 & .497 & .050 \\
\hline Total & 432 & & & & & \\
\hline
\end{tabular}

*Extraversion $=1, *$ Introversion $=2$

Table 4c: Fisher's PLSD For Extraversion (E-1) By Job Specialty

\begin{tabular}{|l|c|c|c|}
\hline Type of Firm & Mean Difference & Critical Difference & P-Value \\
\hline Nat-2-Local vs. National Only & .085 & .169 & .3223 \\
\hline SSNat-2-Local vs. Local Only & -.025 & .096 & .6046 \\
\hline National Only vs. Local Only & -.110 & .169 & .1996 \\
\hline
\end{tabular}

Table 4d: Fisher's PLSD For Extraversion-Introversion (E-1) By Firm Type

\begin{tabular}{|l|c|c|c|c|}
\hline Type of Firm & Mean Difference & Critical Difference & P-Value & \\
\hline Nat-2-Local vs. National Only & .125 & .125 & .0487 & S \\
\hline SSNat-2-Local vs. Local Only & -.135 & .130 & .0419 & S \\
\hline National Only vs. Local Only & -.260 & .103 & $<.0001$ & S \\
\hline & & & & \\
\hline
\end{tabular}

$\mathrm{S}=$ Statistically Significant Difference 
Per Table 2, this study indicates, based on chi-square computations, that there is a statistically significant difference in E-I between those who have worked only for a national CPA firm and those identified as national-tolocal professionals. This study, based on chi-square (Table 2) indicates that with respect to E-I, there is no significant difference between national-to-local professionals and those who had worked only for a local firm. With respect to the comparison of E-I between the CPAs in the national firms and the CPAs in local firms, based on chi-square, there is a statistically significant difference (Table 2 .

When the sample was controlled for gender, per Table 3c, a statically significant difference was found with respect to type of firm and extraversion- introversion for all three combinations of comparisons. Thus while the chisquare calculations per Table 2 found that two of the three comparisons (national vs. local; and national to national-tolocal) statistically significant, when controlling for gender, the Anova per Table 3c, found that all three combinations of comparisons were statistically significant. Upon further analysis it was noted that, in terms of percentages, more female introverts than extraverts were leaving the national firms for the local firms. The opposite was found for the national-to-local firm male CPAs where, in terms of percentages, more male extraverts than introverts ended up working for a local firm. While it was expected that for national-to-local firms CPAs, based on the percentages, more introverted CPAs would be finding jobs with the local firms, this was found to be valid only for the females and not the males. Thus, further research is encouraged to determine why this difference occurred based on gender.

Overall, the hypothesis that the extraversion-introversion percentage rate would be similar regardless of whether a CPA had always worked for a national accounting firm, local public accounting firm, or moved from a national-to-local firm is rejected. Based on this study, it appears that there is a statistically significant difference between extraversion-introversion, for all three types of firms (national only, national-to-local, and local firm only) when controlling for gender and job specialty.

\section{LIMITATIONS}

One of the difficulties with studying public accountants is that, according to Scarbrough (1993), all personality types can be and are successful in public accounting. He notes that the main reason for this fact might be that the skills needed to be successful in public accounting are constantly changing every year as a person moves up the corporate ladder from staff member to partner and or from one assignment to another. So each personality type has many opportunities to find a niche in public accounting that is pleasing to him or her. Scarbrough concluded that flexibility might be one of the primary keys to success or that no one single type is best suited for this profession.

However, according to the theory of psychological type, people who enter occupations in which their type is significantly under-represented may experience difficulty communicating or agreeing with their co-workers, find that the exercise of their preferences is not rewarded, and eventually experience stress or dissatisfaction. Hammer and MacDaid (1992) state that such individuals can survive by finding or creating a special role in an occupation, by working to understand and communicate with others whose preferences are different from their own, and finding other opportunities, such as leisure activities, where they can express their preferences.

Another limitation of this study is that while local firms were divided into two groups (those having worked only for a local firm and those who previously worked for a national firm prior to working for a local firm), no division was made for those, who at the time of this study, had worked only for a national firm. In time, due to high employee turnover, the sample of national firm accountants would eventually be composed of two groups: those who continue their career with the national firm and those who will eventually leave the national firm. This latter group may be significantly different from those who stay employed with a national public accounting firm. Based on past turnover figures, within two years of initial employment, upwards of 50\% of this latter group may not be working with a national accounting firm.

\section{FUTURE RESEARCH}

Since a significant number of national-firm CPAs leave public accounting altogether for private accounting, future research is encouraged to identify the personality types of these individuals who leave national firms for private 
business positions instead of public accounting. Since the turnover rate can be as high as 28 percent for this group, it would be interesting to determine if the personality types of those who enter private accounting is significantly different from those who end up working for local public accounting firms.

\section{CONCLUSION}

Overall, when gender or job specialty is controlled for, the extraversion-introversion differences between those who had only worked for a local CPA, or only for a national firm, or who first started working for a national firm before working for a local firm are statistically different from one another. It is important for people to find employment suitable to their personality, temperament, and talents. Otherwise a person may experience continual frustration and have to keep looking for a proper fit. Introverts need to be aware that if he or she wants $\mathrm{t}$ succeed with a national firm that at least two out of every three CPAs working for a national firm are extraverts. Thus, the up or out mentality, continual socializing for new clients, and the willingness and ability to supervise more people, $\mathrm{s}$ one moves up the corporate latter, is more naturally suited to the extraverts. Thus, the introvert who wants to become a partner in a national firm will have to adapt and be more like the extravert in social and or supervising situations. If the introvert is not willing to compete, then the local CPA may be a good alternative, for his or her personality type, with a local CPA firm.

Even though the national public accounting firms primarily hire those accountants in the top of their graduating class (Scarbrough, 1993), each year nearly 22-28 percent leave national public accounting firms for employment elsewhere. Contrast this finding with the fact that year in and year out local accounting firms have a significantly lower employee turnover rate of seven to ten percent each year. While previous studies have shown that local CPAs are primarily composed of introverts, it is noted that with respect to the national-to-local males in this study, that per Table 3b, that more extraverted males than introverted males are in public accounting with a local CPA firm. This is in contrast to the results per Table $3 b$ where more introverted females from the national firms are seeking employment with local CPA firms than are extraverted females still employed with the national firms. It may be that the working environment of a local CPA firm provides a balanced working environment where both the extravert and introvert can feel comfortable.

\section{REFERENCES}

1. American Institute of Certified Public Accountants. 2002. The Supply of Accounting Graduates and the Demand for Public Accounting Recruits - 2002. New York, New York.

2. $\quad$ Cattell, Raymond. 1965. The Scientific Analysis of Personality. Penguin Books.

3. Consulting Psychologists Press, 1993. General Catalog. 28.

4. Jacoby, Phillip. 1980. An Empirical Descriptive Study of Selected Personality Characteristics of Professional Accountants Based upon Jungian Typology. Dissertation.

5. Hammer, Allen and MacDaid, Gerald. 1992. MBTI Career Report Manual. Consulting Psychologists Press Inc.

6. Myers, Isabel, and MCCaulley, Mary. 1985. Manual: A Guide to the Development and Use of the Myers-Brigs Type Indicator. Consulting Psychologists Press.

7. McCrae, Robert. and Costa, Paul. 1989. Reinterpreting the Myers-Briggs Type Indicator from the perspective of the five-factor model of personality. Journal of Personality. 17-40.

8. Myers, Isabel Briggs and Myers, Peter B. 1980. Gifts Differing. Consulting Psychologists Press. Palo Alto, CA.

9. Otte, Paul. Do CPAs Have A Unique Personality? Spring 1984. The Michigan CPA. 29-36.

10. Satava, David. Spring 1996. Personality Types of CPA (National versus Local Firms). Journal of Psychological Type.

11. Satava, David. Fall 1997. Extraverts or Introverts: Who Supervises the Most CPA Staff Members. Journal of Psychological Type.

12. Scarbrough, D. P. (1993). Psychological Types and Job Satisfaction of Accountants. Journal of Psychological Type, 25, 3-10.

13. Sheridan, John. Organization Culture and Employee Retention. Academy Management Journal. 1992 . p 1036 - 1056.

14. Schloemer, Paul G. and Schloemer, Melanie S. December 1997. Personality Types and Preferences of CPA Firm Professionals. Accounting Horizons. Vol. 11, Issue 4, 24 - 40.

15. Wheeler, Patrick. The Myers-Briggs Type Indicator and Applications to Accounting Education Research. Issues in Accounting Education. Feb 2001. Vol. 16, Issue 1. p 125-140 